\begin{tabular}{l|c|c|}
\hline DE & $\begin{array}{c}\text { DE GRUYTER } \\
\text { OPEN }\end{array}$ & ECONOMIC THEMES (2016) 54(1): 1-20 \\
\hline
\end{tabular}

\title{
THE 'INSTITUTIONS-INDIVIDUAL' CONCEPTUAL NEXUS AS A BASIS OF ALTERNATIVE ECONOMIC METHODOLOGIES
}

\author{
Zoran Stefanović \\ University of Niš, Faculty of Economics, Serbia, Associate Professor \\ $\triangle$ zoran.stefanovic@eknfak.ni.ac.rs \\ Dragan Petrović \\ University of Niš, Faculty of Economics, Serbia \\ $\bowtie$ dragan.petrovic@eknfak.ni.ac.rs
}

UDC

330.837

Review paper

Received:

08.09.2015

Accepted:

23.03.2016

\begin{abstract}
This paper discusses issues of methodological basis of contemporary economic theory, from the perspective of rival research orientations and their conceptual sensitization to the role and impacts of institutional structures. In this regard, the paper presents methodological individualism, research support of economic orthodoxy, based on a consistent interpretation of all social phenomena as outcomes of individual choice. It is shown that even in its most rigid versions this approach has to take to a certain degree into account the social interactions that go beyond the individualist framework. The opposing research orientation, methodological holism, gives explanatory primacy to (different) social collective entities and structures, characteristics of which are autonomous in nature and essential for the explanation of the individual as an entity of a lower order, whose individual properties are not significant. Both approaches are subjected to reductionist tendencies - whether explanations of the socioeconomic reality are individual or culturally over-determined. Integrating institutions in consideration of socioeconomic reality has repercussions on the mentioned methodological dichotomy, given that in conceptual terms it has the potential to bridge the extremely individualistic or collectivist methodological positions. Awareness of the impact of institutions on the socioeconomic reality has produced distinctive methodological orientations. Institutional individualism considers institutions as exogenous mechanism whose explanation is at the service of shedding light on the behaviour of the individuals as the main actors of social dynamics, and in that sense this approach can be considered as a milder variant of methodological individualism. The institutionalist extension of methodological holism, methodological institutionalism, understands individual acting as a product of an integrated institutional framework, whose dynamics takes place independently of the individuals, according to its own regularities. Some kind of balance between the aforementioned orientations is offered by methodological systemism, which affirms the dual nature of the actors of social dynamics - as both product of units of a lower order, but also as entities with autonomous, emergent properties. The contextualisation of relations between institutions and individuals in accordance with a system perspective may be a suitable way, with more tuned reality, theoretical valuation and overcoming differences between opponent methodological traditions.
\end{abstract}

Key words: methodological orientation, individuals, institutions, system.

JEL classification: B31, B4, B52

This paper is a part of the scientific project no. 179066 entitled "Improving Competitiveness of the Public and Private Sector by Networking Competences in the Process of the European Integrations of Republic of Serbia", financed by the Ministry of Education, Science and Technological Development of Republic of Serbia. 


\section{Introduction}

Discussions on the state of affairs in contemporary economic theory conducted in the context of the global economic crisis, are increasingly turning to methodological issues. With its actuality in this regard special attention should deserve the thesis that precisely the shortcomings of methodological assumptions of the economic mainstream are among the major the reasons for the lack of explanatory capacity and inadequacy of practical recommendations of economic theory. In this regard, there are proposals for the implementation of "global methodological purge" (Балацкий, 2012, p. 148), in order to create conditions for the establishment of new methodological principles adapted to the needs of exploration of the complex and layered socioeconomic reality.

An important place in the assessment of the methodological state of affairs within economics is certainly occupied by the fundamental tenet of mainstream - methodological individualism. In this regard, the paper discusses features that significantly limit its epistemological and explanatory power.

Despite the tendency of the majority of economic theoreticians to almost instinctively defend the basic principles of methodological individualism, there is an increasing impression that the dominant interpretation of methodological individualism slowly chokes, because of insisting that science can be made only of the theoretical conclusions that can be reduced to the actions, attributes and decision of individuals. Awareness of this methodological limit led to the establishment of strong and weak version of methodological individualism. This was accompanied by involvement of some holistic elements and entities in this methodological conception. Depending on the intensity of appreciation of the whole and its impact on shaping individual behaviour, three methodological conceptions emerged: institutional individualism, methodological institutionalism and methodological systemism.

The goal of the paper is to examine the significance and relevance of those methodological orientations that consider the institutions-individuals nexus conceptually significant. In this regard, institutionalist oriented methodological approaches will be presented, as well as their relationship to nowadays dominant methodological traditions: methodological individualism (orthodoxy) and methodological holism (present within some heterodox schools of economic thought).

\section{Methodological Individualism as the Conceptual Core of Modern Mainstream}

As in most sciences, the majority of economic theoreticians do their job with little explicit reflection on the methodological assumptions which serve as the basis of their research. However, one of the assumptions that economists, 
despite their reluctant declaration of foundations of economic knowledge acquisition, almost as by rule support, is methodological individualism (Hodgson, 2007, p. 211).

Methodological individualism is some sort of research framework which gathers and unite representatives of neoclassical economics, emphasising that all the concepts used in scientific analysis must be explained starting from the individuals. Such a position of economic theory can be, among other things, justified by its intuitive appeal: namely, it is obvious that social phenomena are the result of the actions of individuals, which is fully consistent with the interpretation of ontological individualism, in which collective phenomena are nothing more than the consequences of hypothetical abstractions derived from the decisions of real individuals (Blaug, 1992, p. 45). Trivial truth is that social phenomena, relations and processes would not exist without individual. Individuals are the building blocks of society and all social phenomena result from their activities, either directly or indirectly (Golubović, 2011, p. 117).

In fact, the essence of methodological individualism is the tendency to conclude about the characteristics of the system based on the properties of its constituent elements. When it comes to society that element is certainly an individual who, as a being with certain needs, engages in economic activity in order to overcome the tension generated by unsatisfied needs and thereby maximise his/her utility. Such a procedure is determined by the act of personal motivation, but individuals cannot act independently and in isolation versus nature, which implies that individuals necessarily enter into relationships with other individuals. In this way, the collective action occurs as a consequence of the activities of the individuals who make up the group, and it is logical that the functioning of the group and even the whole society is a reflection of individual action. This means that all actions taken by individuals and social collectives do not exist outside of action taken by its members (Mises [1949] 1996, p. 42)

The dominant contemporary interpretation of methodological individualism can be illustrated by the attitudes of prominent social scientist. One of them is Harold Kincaid, who devoted more than a decade to developing the concept of methodological individualism. The essential content of methodological individualism he sees in the proposition that the theories related to social entities, social characteristics, and so on, can, in principle, be reduced to purely individualistic theories, and that every social event can be fully explained in purely individualistic terms (Kincaid, 1990, p. 141). In addition to this, methodological individualism does not deny the existence of complex social phenomena, such as institutions, or rules of conduct that apply to a large number of individuals. Such phenomena are a social reality, but their explanation should be based on individual characteristics of the elements from which they are made of. 
It is in this claim, however, that some sort of reductionism can be observed, primarily because it assumes that all socially relevant characteristics of individuals and their actions are autonomous: they include neither other individuals nor social entities, such as groups or institutions (Kincaid, 1998, p. 295). It is, among other things, the reason why Watkins (1953, p. 188) compares the methodological individualism with the methods of natural and physical sciences. On the same line of thinking is Zwirn (2007, p. 49) when he claims that the methodological individualism within social science methods is analogous to the methods typical for physicists, originated in the tradition of Galileo and Newton: it is a method of decomposition of complex situations into their atomic constituents and its simplest principles, as well as the method of deductive reconstruction of the whole situation from them.

Doubts and ambiguities regarding its conceptualisation and implementation are the cause of frequent discussion and controversy even among supporters of methodological individualism. The reason for this should be sought, inter alia, in the fact that it is a metha-theoretical sort of question that is not suitable for empirical testing, which would give unambiguous answers. Therefore, it should not be surprising that among the representatives of the neoclassical and neoAustrian school, as the main protagonists and popularizers of methodological individualism, there are some differences when it comes to specific interpretations of the basic methodological principles of mainstream economics (Petrović, 2008, pp. 190-192).

\section{Methodological Holism}

Economic theoreticians, who are dissatisfied with the epistemological and methodological explanatory capabilities of individualism, generally support the principle of methodological holism. In contrast to individualistic orientation, which suggests that the characteristics of the system can be judged based on the characteristics of the elements that belong to the system, methodological holism is the view according to which the properties of the system can be explained by the system itself. Moreover, the characteristics of the system determine the properties of its constituent elements. (Kitanović \& Petrović, 2010).

Holism is a term that dates back to the South African scientist Jan Christiaan Smuts, and is derived from the Greek word ó $\lambda \varepsilon \xi$, meaning whole. It is the term used for the purpose of identifying and categorising new types of theories with the dominant presence of the evolutionary and dynamic characteristics, which is the case, for instance, with the Darwinian theory of evolution, Becquerel's theory of radioactivity and Einstein's theory of relativity. This post-Darwinian type of scientific thought, which Smuts described as holistic, interprets the physical world as a development of a dynamic whole, as opposed to atomistic theories that propagated the static and deterministic view 
of the world. Unlike Newton and other pre-Darwinian theorists, a whole, according to the above-mentioned opinion, is more than the sum of its parts, where these parts are so interrelated that their very existence is conditioned by the mutual relations and connections (Wilber and Harrison, 1978, p. 73).

Holism as a methodological orientation asserts that the basic social phenomena are supra-individual social categories; therefore, their explanation cannot be made based on the use of individual-oriented concepts. Holistic approach points out that in order to improve knowledge and understanding of a system, one should not disassemble it on its constituents. It is necessary to do just the opposite - the system should be considered in aggregate terms, which will contribute to better perception of the qualities, nature and purpose of the system. This means that epistemological holism opposes reductionism, whereby the expression of reductionism in economic theory (according to this viewpoint) is primarily found in the principle of methodological individualism (Кирдина, 2013 , p. 75). According to the same interpretation, holism is a form of antireductionism which implies that the properties of a given system cannot be explained solely by the properties of its component parts.

Since the dynamic wholeness and integrity of the economic system is provided by the functioning of its institutional arrangements, it is not a surprise that among most prominent interpretations of holistic principles within economic theory are those by representatives of institutional economic theory. After all, the development of the institutionalism in economic theory is in a way pervaded by a debate between the methodological individualism and methodological holism the major matter of dispute is which of the mentioned methodological patterns is relevant for institutional analysis of organisational change (see: Langloiss, 1989; Hodgson, 1988). Thus, among the representatives of the "new institutionalism" is the majority of those who rely on the principle of methodological individualism, while methodological holism is the hard core for the most of representatives of traditional institutionalism (Toboso, 2001, p. 767).

The reason for the sharp methodological distinction between old and new institutionalism can certainly be found in the fact that the new institutionalism in the 1970s of the twentieth century was integrated into the very core of neoclassical theory, and is distanced from the traditional institutionalism of the late nineteenth and early twentieth century. Therefore, the new institutional economics relies heavily on the apparatus of neoclassical analysis (Stefanović, 2009 , p. 35), without pretension to a significant revision of orthodox economics (Blaug, 1985, p. 710), which, among other things, induced Williamson to conclude that institutional economics is actually incorporated into the economic orthodoxy (Williamson, 2000, p. 596).

Aside from confrontation between methodological individualism and methodological holism, it should be noted that in the domain of interpretation of 
holistic concepts there are certain disagreements, which are, among other things, the result of various philosophical roots of reaffirmation of holism (Demeulenaere, 2000, p. 7), as well as unreconciled positions on evaluation of the strength of a specific social reality (Wilber \& Harrison, 1978, p. 80). Thus, there are views that it significantly affects individuals, but also there are interpretations that characteristics of the social order fully determine the behaviour of individuals (Rutherford, 1994, p. 29). For example, one version of methodological holism, which Elster (1985) calls the methodological collectivism, emphasises that the relationship between individuals is of a secondary importance for the explanation of social phenomena, since they are generated by the operation of the whole and, by themselves, do not explain a thing. For these reasons, there is present a belief by many authors that the proponents of a holistic approach are nothing more than the exponents of unrealistic oversocialisation of human behaviour, so-called cultural determinism (Granovetter, 1985).

\section{Institutional Individualism}

Resistance to the original interpretation of methodological individualism includes several authors, among whom should be noted Kontopulos (1993), Blaug (1999), Nozick (1977) and Hodgson (2007). Thus, for example, Kontopulos (1993, p. 79) believes that the strategy of methodological individualism inevitably involves reference to social relations, and social phenomena cannot be realistically eliminated and swept under the rug. Referring to the pronouncedly represented opinion that the macroeconomic theory must be based exclusively on micro-foundations, Blaug in his review of the Kincaid book (Blaug, 1999, p. 249) notes that one of the hallmarks of such conceived theory is that it unconsciously allow holistic interpretations and explanations. This, he notes, does call into question the idea of offering an objective philosophical assessment of methodological individualism. For Nozick (1977), support or denial of methodological individualism is primarily a question of sustainability of a priori theory of human action (Block, 1980, p. 397). The possibility of reducing the social science to the theories of individual human action, he associated with a dilemma whether it is possible to reduce the theory of interaction, for example, of two people to a theory of individual human action. In this regard, he reminds that economists, in understanding this problem, like to use an example of Robinson Crusoe. Crusoe, in an effort to meet his needs, individually make decisions on how to deploy time and supplies, what to spend earlier and what later. It is, therefore, a theory of individual decision making under risk and uncertainty. With this in mind, the question is whether the interaction of two or more persons only specifies the previous Crusoe theory applied in particular circumstances, or introduce something new and irreducible. 
The aforementioned problems related to the explanation of social phenomena, Hodgson (2007, p. 220) associated with the apparent confusion that reigns in the original interpretation of the methodological individualism:

- Social phenomena should be explained starting from the individuals and their actions; or

- Social phenomena should be explained starting from individuals plus relations between these individuals;

The first of these versions, Hodgson (2007) believes, has never been realised in practice. According to the individualistic approach, based on the recognition of individuals as isolated individuals, the whole may not exhibit certain characteristics or quality if the components do not have that feature or quality. System performance simply reflects the characteristics of the components, thus emerging properties are excluded. However, individualism is precisely criticised for not taking into account the relationship between the actors and their influence on the occurrence of certain properties at a macro or systemic level, which are not present at the level of individuals. It is an undeniable fact that the individual is still a social being, which is usually involved in relationships with others, with the result of this action in a new quality. Hence the idea of a completely isolated individual, freed of social relations, is in fact untenable (Davis, 2003).

In other version, however, the question of the justification of the use of the term methodological individualism arises, since it recognises the existence of interactive relations between individuals. Thus, analysis includes the important holistic elements, and opens the door at the theoretical level for the recognition of concepts such as institutional and structural individualism.

Based on this, it can be concluded that the basis of criticism of methodological individualism is that it is absolutisation, or at least overestimation of the role of the individual. It follows that the methodologicalindividualistic orientation is reductionist to the extent it insists that the true theory of the social sciences is reducible to the theory of individual human action. With a critique of methodological individualism one may also connect the very critique of economic orthodoxy since the reductionist project of the mainstream economics has its roots precisely in the support of methodological individualism (Davis, 2003, p. 35). Strict interpretation of methodological individualism could have potentially unfavourable repercussions for economic science, since it would instruct abandoning all macroeconomic proposals that cannot be reduced to microeconomic foundations, which would mean to forget macroeconomic theory as such (Blaug, 1992, p. 46). It would also fuel the already widely present trend, the affirmation of economic imperialism and the application of microeconomic principles to the analysis and explanation of 
phenomena that, in principle, do not belong to the field of study of economic science (Petrović \& Stefanović, 2013).

Institutional individualism is a version of methodological individualism exhibited by Agassi (1960, p. 247). The inspiration for his position on individualism he found in Popper's initiation of conflict between psychologism and institutionalism. In fact, there is a general understanding that Karl Popper is one of the most consistent advocates of methodological individualism, primarily because of its insistence that it is a postulate, undeniable or zero doctrine which must be assumed in order to explain social phenomena (Popper, [1957] 1961, p. 136).

Although Popper is consistent in his belief that society is composed of individuals, and that in explaining social phenomena one should start from individuals, he was still of the opinion that this methodological position should be distinguished from psychologism. Psychologism, he claims, may be correct to the extent that it opposes methodological collectivism, insisting that all social phenomena, in particular the functioning of all social institutions, must be understood as something that is derived from the decisions, actions and behaviours of individuals. However, the questionable belief of psychologism is that the choice of method of individualistic approach necessarily reduces down to the use of psychological methods. That is why instead of psychologism, Popper proposes a methodology based on situational logic and institutional environment (Udehn, 2002, p. 488). In this way, institutionalism is becoming an alternative to psychologism, which implies that the actions of individuals cannot be explained without taking into account the impact of social institutions (Popper, [1945] 1960, p. 90).

Unlike the original version of methodological individualism, institutional individualism explicitly includes social institutions in the interpretation of individual behaviour. Among the most important protagonists of institutional individualism, which can be understood as a kind of confrontation to psychological individualism, should be included Agassi (1960, 1975), Jarvie (1972) and Boland (1982). Agassi considers this concept a new version of methodological individualism, although he does not use this term later on (Agassi, 1975, cited by: Udehn 2002, p. 489). According to his view, the behaviour of individuals is defined not only by their goals, but also by the institutions within which they operate (Agassi, 1960, p. 247, cited by: Udehn, 2002). Jarvie elaborates institutional individualism of Agassi, by the affirmation of the thesis that social institutions are as specific and real as the physical environment is (Jarvie, 1972, by: Udehn 2002, p. 489).

Although the institutional individualism, according to the opinion of the mentioned authors, can be seen as a version of methodological individualism, there are significant differences between the two concepts. Thus, according to the methodological individualism, social institutions are explained as a result of 
human behaviour. They appear only in explanandum or the result of explanation, and never in explanans or set up. In contrast, institutions from the perspective of institutional individualism have the features of exogenous variables, in the range of psychological and natural constraints (Boland, 1982, Ch. 2). This means that they have become a key factor from which explaining of human behaviour starts, and therefore, must consequently appear in explanans, or setting explanations.

The explanatory power of institutional individualism is based on a fairly widespread belief that it is a form of non-reductionist explanation, which, within economic theory, includes institutional aspects of interaction of individuals (Toboso, 2001, p. 766). Consequently, it can be linked both to the traditional institutional economics and its commitment to a holistic approach, as well as to new institutionalists who still have not managed to break away from the "hug" of methodological individualism. Hence, a pertinent question occurs whether institutional individualism can serve as an adequate basis for convergence of methodological viewpoints of traditional and new institutionalism.

The main characteristic of institutional individualism is that the explanation of human behaviour is not based solely on the assumption of rationality, but it is viewed in the broad context of social behaviour determined by norms and rules. Since the norms, inter alia, can be defined as a framework within which individuals interpret the current situation and recognise their responsibility (Fine, 2001, p. 140) it can be concluded that, instead of homo oeconomicus, a research focus of institutional indvidiualism diverts to homo institutius. Accordingly, one must proceed from three basic assumptions, or the three basic rules of institutional individualism (Toboso, 2001, p. 773).

1. Only agents may have goals and promote their interests; which aparts institutional individualism from methodological holism. The aforementioned assumption means that there are no impersonal systemic factors that have their own dynamics beyond the influence of individuals.

2. Formal and informal institutions influence the interactions between people, and as such can be part of the explanatory categorisation. The validity of this assumption is in the distancing of institutional individualism from methodological individualism.

3. Marginal institutional changes are always the result of independent or collective action of some subjects that is typically achieved within a broader institutional framework.

It can be concluded that the attention of researchers within this orientation primarily focus on the analysis of interpersonal action on the basis of respecting the standard assumption of full rationality of economic actors, while a circle of factors that affect economic behaviour includes the institutions. Hence, the widespread opinion that this approach is actually a softer variant of 
methodological individualism, according to which both the micro and the macro-economic effects should be primarily seen as a result of interaction of independent actors within existing institutions (Полтерович, 2011, p. 107).

\section{Methodological Institutionalism}

It is necessary to recall that both methodological holism and methodological individualism, have their own epistemological and ontological content (Petrović, 2012, p. 94). An expression is said to be ontological when it denotes what exists. On the other hand, it takes a methodological context when talking about the way of explanation and interpretation of certain phenomena. In terms of the normative framework of its own functioning every economic system can be considered a kind of a complex of institutional arrangements - market and non-market (Hodgson, 1999), formal and informal (North, 1990), associative, behavioural, cognitive, regulatory, constitutive (Part 2005, p. 39). In this regard, the institutional structures have found their place as an object of interest of a holistic approach. Hence, in light of the issues related to the relevance and adequacy of methodological terms and concepts, there is the claim that the proper implementation of methodological holism in economic research should be labelled methodological institutionalism (Кирдина 2013, p. 78).

The term methodological institutionalism implies the approach to research of all social phenomena, and in this sense economic systems (from micro to macro level) as well, based on the interpretation of the whole and the aggregate effects of formal and informal institutions, where the dominant explanation of social phenomena uses the instruments of modern institutional theory (Фролов, 2008). Methodological institutionalism should not be understood exclusively in the ontological sense, especially when one considers the institutions as an object of analysis. It is actually a different vision of economic reality, when the basic institutions have become a research guide on the path of observation of and gaining knowledge about economic phenomena. Within the methodological analysis of institutions the crucial problem of research is theoretical establishing of a stable institutional system that regulates the behaviour of economic actors and the association of their activities with the rules of conduct, both at the micro and macro level.

In order to understand this aspect of the institutions reference may be made to North's notion that institutions are the rules of the game of society; restrictions designed by people that structure human interaction (North, 1990, pp. 3-5), Accordingly, an individual cannot be characterized only in terms of naturally predetermined entity, ie. he cannot be seen as given. Instead, it is more realistic to assume that the so-called initial hypothetical state of nature already has certain rules, cultural and social norms (Hodgson, 1998, p. 177). Therefore, it is desirable to correctly determine the ontological status of institutions and individuals, 
particularly in terms of recognising that individuals are born into a society with a defined and fully established institutional structure.

In terms of the abovementioned institutions - individuals context, methodological institutionalism can be interpreted as a kind of attempt at a synthesis of methodological collectivism as a macro approach and methodological individualism as a micro approach (Keizer, 2007, p. 20). Thus the "transition" from the micro to the macro level of observation should not be connected with the model of a simple aggregation of individuals within the functioning of certain collectives and the economy as a whole. As its essential feature methodological institutionalism states the possibility of identifying new quality. The study of this quality is the responsibility of macroeconomic analysis, whereby its qualitative properties are neither recognisable nor characteristic for observed individual behaviours.

In addition to this, there are arguments indicating that interactions between individuals result in the emergence of phenomena at the system level (Coleman, 1990, p. 5; cited in: Bunge, 2000, p. 149), the emergence of new properties as a result of interaction of certain entities, where the entities themselves do not have these properties (Hodgson, 2007, p. 220). In this regard, Lawson (1997, p. 176) explains that each newly created entity is actually derived from a lower level, and is, among other things, caused by its own existence and functioning. This, however, does not mean that this new entity can be predicted on the basis of characteristics of entities that exist at lower levels.

The practical realisation of methodological institutionalism in economic research is associated with attempts to determine the rules and laws of economic behaviour in accordance with the institutional set-up of economic processes (Polanyi, 1957, p. 248). The relevance of this approach, according to Polanyi, is that it emphasises the importance of social and historical, and it is a kind of distancing from the narrow viewpoint of neoclassical economic theory. The conception of society of this author is based on the interaction between individuals and social institutions. In order to understand certain activity, the research must be placed in a social context, and, to understand the social context, we must turn to the history, to the interactions between social institutions and the individuals that determined the social context.

Polanyi (1957), therefore, instead of scarcity, choices, deficits, as concepts used by the economic mainstream, focuses on the analysis of social conditions which determine the stability of the economic process, giving primacy to the functioning of economic and non-economic institutions in which economic process is rooted. Over the last few decades, such views in social science has been partly integrated within the concept of embeddedness, in order to indicate that the behaviour of individuals and institutions is determined by social relations. Individuals in reality do not act as isolated atoms, which should be 
sufficiently compelling reason for abandoning the fiction that society is composed of a set of independent individuals that realise their goals fully autonomously and independently (Coleman, 1990, p. 300, cited in: Bunge, 2000 , p. 149). Instead, individuals should be displayed in a particular context, with the rules of conduct that govern their behaviour (Field, 1979). They are woven into the structure of social networks, which are relevant in explaining economic performance. The concept of embeddedness refers to the social, cultural, political and cognitive frameworks in which economic decisions are made and points to the unbreakable bond between actors and their social environment (Granovetter, 1985).

\section{Methodological Systemism versus Methodological Institutionalism}

Methodological institutionalism, as mainly holistic methodological orientation, certainly adds a new quality in the analysis of social and economic reality. However, the holistic approach is not immune from uncritical interpretations, which can turn it into a typical one-sided analysis of social phenomena and conducting scientific research (Hodgson, et al., 1994, p. 64).

It turns out, therefore, that with both rival methodological approaches there is a danger of turning into reductionism - in methodological individualism starting exclusively from individuals in explaining and analysing society (Watkins, 1953; Arrow, 1994), and in methodological holism taking the whole as the baseline. Individualistic approach is subject to the already listed deficiencies related to analytical defects of atomistic ontology. On the other hand, holistic orientation, focused on macro phenomena may lose empirical foundation and turn into speculation (Wilber \& Harrison, 1978, p. 83).

Precision and accuracy, inherent to individualistic approach, provide empirical or logical control, while, on the other hand, the vagueness and suggestivity of holism encourage creativity, but are exposed to risk of uncontrolled speculation. Therefore, the central problem of proper methodology is to reconcile these methodological qualities, and to connect them into synergistic effect (Wilber \& Harrison, 1978, p. 84).

Shortcomings and weaknesses of both individualism and holism as methodological procedures prompted thinking about a new methodological direction that could overcome their reductive characteristics. Since the methodological institutionalism is only a form of expression of methodological holism, the opinion of some authors is that it does not meet the criteria necessary for methodology to arrive at valid scientific knowledge. Thus, for example, Bunge (2000) advocates the implementation of new methodological direction - methodological systemism known also as emergentist systemism, as a middle way between methodological individualism and methodological 
holism, superior in relation to both of these approaches. In his book "Systemism: an alternative to individualism and holism" (Bunge, 2000), he states that none of the two methodological approaches to research in social science, is adequate, and if used alone is completely flawed. Methodological individualism, in his opinion, is wrong because it underestimates or even overlooks connections between people, whereas methodological holism is mistaken to completely ignore the importance of individual activities (ibid., p. 156).

According to Bunge, each system is a complex phenomenon whose elements are interconnected in a way that generate certain properties of the system, which are not possessed by its elements, which is known as the principle of emergence (Bunge, 1996, cited by: Kapeller, 2016). Emergent properties, as a sort of mechanisms, some of them unique to the system, manage its dynamics. Mechanisms carry the recipes for the performance of functions that address the specific goals. In principle, for the purpose of performing the same function can serve various mechanisms (Bunge, 1996, cited by: Kapeller, 2016). Each system is determined by the arrangement of its elements, its environment and the way relations within and between its components are structured. The manner in which the relations between components of the system are orgasized defines its emergent properties and its mechanisms. Precisely this component of the system is in the centre of attention of methodological systemism (Kapeller, 2016). The fact that the actors of the relations within the system are both ndividuals and coherent higher level wholes justifies the need that the study of the system relations in equal measure take into consideration both individual and collective entities. This mode of research can in way overcome both individualistic and holistic reductionism (ibid, 2015).

Furthermore, each component of the system may itself constitute a system with a specific hierarchical organisation of the lower sub-systems and constituents. In this sense, the socioeconomic reality can be seen as a kind of hierarchy of systems, each representing an entity with emergent properties, but also serving as a constituent unit of a higher order system. Thus, viewed from a systems perspective, science is actually studying phenomena as the sets of systems at different levels of the hierarchy. The links between them, depending on the context, are established in accordance with "top-down" or "bottom-up" principle (ibid, 2015). The relative importance and the position from each of the system is viewed (i.e. system or subsystem, micro- or macro perspective,) are contextually conditioned.

Methodological systemism, therefore, provides space both for organisation and structure by affirming perception of the phenomena from the perspective of the system - everething is a system or the component of a system - whereas any system has its own characteristics (in progress) that its components do not possess (Bunge, 2000, p. 147). It is the methodological procedure which affirms the double nature of system elements - each of them masters the independent 
capacity as an autonomous unit, but also has dependent properties which are determined by the corresponding elements of the system as a whole (Kitanović $\&$ Petrović, 2010, p. 80). This means that the system is one that influences the properties of its constituent elements, but not completely. The system also adopts features of its own components, but in the process of formation assumes the properties that these components do not possess. In this way, a response to the question of what is of a primary importance in explanation - micro- or macro phenomena - is given, highlighting equal importance of mentioned dimensions of social reality. In the context of economic theory, this means that both micro- and macro phenomena and "laws" are equally important and that they must be analysed as relatively independent entities, but one should put emphasis on their synergy as well.

Depending on the basic methodological starting points one can provide the typology of economic policy. Methodological individualism is typically associated with individualistically oriented policy that does not recognize the social cost while methodological holism is associated with the centralised policy that is devoid of respect for the individual. In contrast, the methodological systemism leaves room for both the agent and the structure, equally respecting individual and social values (Bunge, 2000, p. 153).

This approach shows significant complementarity with the stream of institutional economics, known as Veblenian institutionalism. The similarity is primarily manifested in the general orientation to view reality as a hierarchical structure, where the entities in hierarchies are products of lower order units, but at the same time they are inputs, components for the construction of higher level layers. Such an approach of Veblen's followers is the product of their reliance on organicist ontology, aimed at overcoming the Cartesian dichotomy of physical and mental worlds, by the introduction of the view in which they are combined into a single establishment, which is characterised by the emergence of independent entities from the lower hierarchical structures. In contrast to Cartesian atomism, organicistic ontology, in the interpretation of Veblen's followers, considers the whole universe a stratified organisation, where each level is a kind of organism connected with the environment, whose functional characteristics are not readily apparent from its constituent elements. (Hodgson, 1995, p. 482). Also, methodological systemism and Veblenian (as well as new) institutionalism, share an interest in problems of organization of relationships within and between systems. The structuring of social relations is the subject of institutional arrangements. As a kind of invisible, but a firmly established network of behavioural patterns at different levels of the hierarchy of social organisation, institutions serve to support the survival of the system. They define inclination of individuals to certain types of behaviour, shape their motivation, regulate property relations, induce collective preferences for certain 
forms of social organisation and so on. Their action pervades and maintains the coherence of hierarchy of socioeconomic systems.

It can be concluded that institutional structures are the closest conceptual expression of what methodological systemism considers a "mechanism". In socioeconomic systems, institutional arrangements, distinctive for each nation, carry the recipes for the performance of functions, whereby one objective can be achieved by alternative mechanisms, assembles of institutional arrangements. Perhaps a suitable illustration of this conclusion can be found in comparative political economy, where national economies are classified into models of capitalism, depending on how their culturally and historically established institutions are performing economic coordination, as the universal function of each social system (Gilpin, 2001). Similarly, Rodrik (2005) argues that in development economics objectives are clear and unambiguous: protected property rights, rule of law, market motivation of actors, sustainable public finances, stable currency. The way to achieve these goals, however, is not universal. Numerous mutually different sets of institutional arrangements can be employed for the purpose of their implementation. Awareness of the importance of the institutional structures has also important implications for the modelling of economic reforms, which must have a great deal of tact to existing, often strongly established patterns of interaction between the actors of the system, in order to avoid sudden disruptions in the coordination and incidental destructive socioeconomic trends.

\section{Conclusion}

The principles of methodological individualism are integrated in the categorical core of economic mainstream, building a general methodological position of neoclassical economics. As such, this approach has retained its primary meaning in the framework of orthodox economics, ensuring some sort of gradual "expansion" of knowledge frontiers of the mainstream economics, and the possibility of permanent synthesis with new knowledge from the economictheoretical approaches that developed during the twentieth century.

Despite the fact that methodological individualism enabled the creation of very suggestive and logically convincing conception of socioeconomic phenomena, one cannot ignore a growing doubt into its explicative and predictive power. The belief that society is made up of individuals and nothing else, does not mean that all social and economic phenomena can be explained solely in terms of individuals and their actions.

In circumstances when methodological individualism brings a number of analytical difficulties, which, among other things, calls into question its suitability to the study and analysis of contemporary economic phenomena, 
non-surprising is the re-emergence of interest for alternative methodological orientations. Basically, new methodological positions claim that any relevant explanation, originally based on methodological individualism, in fact unwittingly allows the inclusion of certain holistic concepts and system components. The extent to which this is present depends on the intensity of distancing from methodological individualism and the expression of the need for aggregate approach to the subject of research. In this regard, weak and strong versions of methodological individualism and holism can be identified. Thus, for example, the key features of methodological individualism, suffer the least collapse in the case of institutional individualism, since institutional individualism is mostly seen as a milder form of methodological individualism.

Methodological institutionalism can be understood as a way of realisation of methodological holism in the process of understanding the essence of the functioning of the economy and society. Regardless of the presence of arguments that justify the position of methodological holism, especially in the context of creating the conditions for a reliable interpretation of reality and understanding the emergence of social and economic phenomena, one must not ignore the warnings that the uncritical application of this methodological procedure is just another form of reductionism in economic research.

To avoid this possibility, the acceptance of methodological institutionalism should not be conducted in a way that represents and promotes the methodological extremism embodied, among other things, in the methodological collectivism and cultural determinism. Instead, it is more appropriate to consider methodological institutionalism in the context of creating conceptual prerequisites for the improvement of the economic analysis, without starting the infinite regression related to who should be given the primacy in the overall explanation - institutions or individuals.

Slight movement of holistic methodological approach in the direction of balanced position that both institutions and individuals are equally relevant entities of the entire social system can definitely alleviate the reductionist features of contrasting methodological starting points and significantly reduce the tendency towards one-sided conception of the individual - society relationship. To this end, it is worth it to look at the instructions of methodological systemism and similar research patterns, that, in the light of antireductionist explanations of socioeconomic phenomena, contribute to their better and more complete understanding.

\section{References}

Agassi, J. (1960). Methodological individualism. British Journal of Sociology, 11(3), 24470.

Agassi, J. (1975). Institutional individualism. British Journal of Sociology, 26(2), 144-156. 
Arrow, K. (1994). Methodological Individualism and Social Knowledge., American Economic Review, 84(2), 1-9.

Blaug, M. (1985). Economic Theory in Retrospect, (4 ${ }^{\text {th }}$ ed). Cambridge: Cambridge University Press.

Blaug, M. (1992). The Methodology of Economics or How Economists Explain, (2 ${ }^{\text {nd }}$ ed.). Cambridge: Cambridge University Press.

Blaug, M. (1999). Individualism and the Unity of Science. Esays on Reduction, Explanation and the Special Science, By Harold Kincaid, 1997.( pp. 249-251). , Oxford: Rowman \&Littlefield Publisher

Block, W. (1980). On Robert Nozick's 'On Austrian Methodology'. Inquiry, 23(4), 397-444.

Boland, L. (1982). The Foundations of Economic Method, London: Allen\&Unwin.

Bunge, M. (1996). Finding Philosophy in Social Science. Yale University Press.

Bunge, M. (2000). Systemism: the alternative to individualism and holism. The Journal of Socio-Economics, 29(2), 147- 157.

Coleman, J. (1990). Foundations of Social Theory. Cambridge, MA: Harvard University Press.

Davis, J. (2003). The Theory of the Individual in Economics: Identity and Value. London and New York: Routledge.

Demeulenaere, P. (2000) Individualism and Holism: New Controwersies in the Philosophy of Social Science. Mind \& Society, 2(1), 3-16.

Elster, J. (1985). Making Sense of Marx, Cambridge. UK: Cambridge University Press.

Field, A. J. (1979). On the explanation of rules using rational choice models. Journal of Economic Issues, 13(1), 49-72.

Fine G. (2001). Enacting Norms: Mushrooming and the Culture of Expectations and Explanations. In: Hechter, M. \& Opp, K. (eds.), Social Norms, Russell Sage Foundation.

Gilpin, R (2001). Global Political Economy. Princeton: Princeton University Press.

Golubović, N. (2011). Društvena ekonomika - Ekonomska aktivnost u društvenom okruženju. Niš: Ekonomski fakultet, Univerzitet u Nišu.

Granovetter, M. (1985). Economic Action and Social Structure: The Problem of Embeddednes. American Journal of Sociology, 91(3), 481-510.

Hodgson, G. (1988). Economics and Institutions: A Manifesto for Modern Institutional Economics, Cambridge: Cambridge University Press.

Hodgson, G (1995). The Evolution of Evolutionary Economics. Scottish Journal of Political Economy, 42(6):469-488. doi: 10.1111/j.1467-9485.1995.tb01172.x

Hodgson, G. (1998). Aproach of Institutional Economics. Journal of Economic Literature, 36(1), 166-192.

Hodgson, G. (1999) Economics and Utopia: Why the Learning of Economy is not the End of History. New York: Routledge

Hodgson, G. (2007). Meanings of Methodological Individualism. Journal of Economic Methodology, 14(2), 211-226.

Hodgson, G.,W. Samuels, J. \&. Tool M. R (Eds.) (1994) The Elgar Companion to Institutional and Evolutionary Economics, L-Z. Aldershot: Edward Elgar.

Jarvie, I. C. (1972). Concepts and Society. London: Routledge \& Kegan Paul. 
Kapeller, J. (2016). Beyond Foundations: Systemism in Economic Thinking, In: Jo, T-H. \& Todorova, Z. (Eds.) Advancing the Frontiers in Heterodox Economics: Essays in Honor of Frederic S. Lee, (pp. 115-134). London and New York: Routledge.

Keizer, P. (2007). The Concept of Institution in Economics and Sociology, a Methodological Exposition. Discussion Paper Series nr: 07-25, Tjalling C. Koopmans Research Institute, Utrecht School of Economics, Utrecht University.

Kincaid, H. (1990). Eliminativism and Methodological Individualism. Philosophy of Science, 57(1), 141-148.

Kincaid, H. (1998). Methodological Individualism/Atomism. in Davis, J., Hands, D. W. \& Mäki, U. (eds.), Handbook of Economic Methodology, Cheltenham, U. K.: Edward Elgar, pp. 294-300.

Kitanović, D. \& Petrović, D. (2010) Ogledi o metodološkim problemima savremene ekonomske nauke. Niš: Ekonomski fakultet, Univerzitet u Nišu.

Kontopoulos, K. M. (1993). The Logics of Social Structure, Cambridge: Cambridge University Press.

Langlois, R. (1989). The New Institutional Economics: an Introductionary Essay. in Langlois, R. (Ed.). Economics as a Process: Essays in the New Institutional Economics, (pp. 1-25.) New York: Cambridge University Press.

Lawson, A. (1997). Economics and Reality, London: Routledge.

Mises von, L. (1949)1996. Human Action: A Treatise on Economics, ( ${ }^{\text {th }}$ revised ed.). San Francisko: Fox and Wilkes.

North, D. (1990). Institutions, institutional change and economic performance, Cambridge: Cambridge University Press.

Nozick, R. (1977). On Austrian Methodology. Synthese, 36(3), 353-392.

Parto, S. (2005). Economic Activity and Institutions: Taking Stock. Journal of Economic Issues. 39(1), 21-52.

Petrović, D. (2008). Methodological individualism - criticizing and superseding possibilities. Facta Universitatis: Series economics and organization, 5(3), 185-194.

Petrović, D. (2012). Epistemološke i ontološke pretpostavke metodološkog individualizma. Ekonomske ideje i praksa, 7: 91-100.

Petrović, D. \& Stefanović, Z. (2013). Economic Science in the Light of the Economical Theoretical Imperialism Development, In: Marinković, S. \& Rochhia, S. (Eds.), Rethinking Europe after the Economic Crisis, Lessons for the European Core and Periphery, (pp. 247-265). Niš: Faculty of Economics, University of Niš,

Polanyi, K. (1957). The Economy as Instituted Process. in Polanyi, K. et.al.(eds.), Trade and Market in the Early Empires. (pp. 243-270). New York: Free Prees

Popper, R. K. (1945)1960. The Open Society and Its Enemies, Volume 1: The Spel of Plato, Vols. 2., Hegel and Marx, London: Routledge Kegan\& Paul.

Popper, R. K. (1957)1961. Poverty of Historicism. London: Routledge and Kegan Paul.

Rodrik, D. (2005). Growth Strategies, in: Aghion, P, \& Durlauf, S (eds.) Handbook of Economic Growth Vol. 1A, North Holland.

Rutherford, M. (1994). Institutions in Economics, Cambridge: Cambridge University Press.

Stefanović, Z. (2009). Institucionalistički pravac ekonomske misli, Beograd: Zadužbina Andrejević. 
Toboso, F. (2001). Institutional Individualism and Institutional Change: The Search for a Middle Way Mode of Explanation. Cambridge Journal of Economics, 25(6): 765 783. doi: $10.1093 / \mathrm{cje} / 25.6 .765$

Udehn, L. (2002). The Changing Face of Methodological Individualism. Annual Review of Sociology, 28, 479-507. doi: 10.1146/annurev.soc.28.110601.140938

Watkins, J. (1953). The Principe of Methodological Individualism. British Journal for the Philosophy of Science,3(10): 186-89.

Wilber, C. K. \& R. S. Harrison (1978). The Methodological Basis of Institutional Economics: Pattern Model, Storytelling, and Holism. Journal of Economic Issues, 12(1): 61-89.

Williamson, O. (2000). The New Institutional Economics: Taking Stock, Looking Ahead. Journal of Economic Literature, 38(3), 595-613.

Zwirn, G. (2007). Methodological Individualism or Methodological Atomism: The Case of Friedrich Hayek. History of Political Economy, 39(1), 48-80. doi:10.1215/00182702-2006-005

Балацкий, Е. В. (2012). За пределами економического империализма: Преоделение сложниости. Общественные науки и соврееменность, 4, 138-149.

Кирдина, С. (2013). Методологическийиндивидуализм и методологический институционализм. Вопросы экономики, 10, 66-88.

Полтерович В. М. (2011). Становление общего социального анализа/ Общественные науки и современность, 2, 101-111.

Фролов Д. П. (2008). Методолгическийинститутионализм: новый взгляд на эволюциюэкономической наук. Вопросы экономики, 11, 90-101.

\section{KONCEPUTALNA SPONA 'INSTITUICIJE-POJEDINCI' KAO OSNOVA ALTERNATIVNIH EKONOMSKIH METODOLOGIJA}

Apstrakt: U radu se razmatraju pitanja metodoloških polazišta savremene ekonomske teorije, iz perspektive rivalskih istraživačkih orijentacija i njihove konceptualne senzibilizacije na ulogu i dejstva institucionalih struktura. U tom smislu najpre se prikazuje metodološki individiualizam, istraživački oslonac ekonomske heterodoksije, zasnovan na konzistentnom tumačenju svih društvenih fenomena kao ishoda individualnog izbora. Pokazuje se da čak i svojim najrigidnijim verzijama pomenuti pristup mora $u$ određenom stepenu uzeti $u$ obzir društvene interakcije koje fenomenološki nadilaze okvire individualnog. Oponentna istraživačka orijentacija, metodološki holizam, daje eksplanatorski primat (različitim) društvenim kolektivitetima i strukturama, čija su obeležja, autonomna po svojoj prirodi, esencijalna za objašnjenje pojedinaca kao entiteta nižeg reda, čija individualna svojstva nisu od većeg značaja. Oba pristupa podložna su redukcionističkim tendencijama - bilo da su objašnjenja društveno-ekonomske stvarnosti individualistički ili kulturno naddeterminisana. Integrisanje institucija u promišljanje društveno-ekonomske stvarnosti, ima reperkusije i na pomenutu metodološku dihotomiju, s obzirom da $\mathrm{u}$ konceptualnom smislu poseduje potencijal premošćavanja ekstremno individualističkih ili kolektivističkih metodoloških pozicija. Svest o uticaju institucija na društveno-ekonomsku stvarnost produkovala je osobene 
metodološke orijentacije. Institucionalni individiualizam institucije smatra egzogenim mehanizmom čije objašnjenje je u službi rasvetljavanja ponašanja pojedinca kao glavnog aktera društvene dinamike, te se $u$ tom smislu može smatrati blažom varijantom metodološkog individualizma. Institucionalistička ekstenzija metodološkog holizma, metodološki institucionalizam, shvata individulano delanje kao produkt integrisanog institucionalnog okruženja, čija se dinamika odvija nezavisno od pojedinaca, po sopstvenim zakonomernostima. Neku vrstu balansa između pomenutih orijentacija nudi metodološki sistemizam, koji afirmiše dualnu prirodu aktera društvene dinamike - kao produkta jedinica nižeg reda, ali i entiteta sa autonomnim, emergentnim svojstvima. Kontekstualizacija odnosa između institucija i pojedinaca u skladu sa sistemskom perspektivom, može biti podoban način njihove realnosti primerenije teorijske valorizacije i prevazilaženja razlike između oponentnih metodoloških tradicija.

Ključne reči: metodološke orijentacije, individue, institucije, sistem.

\section{Authors' biographies}

Zoran Stefanović is an associate professor at the Faculty of Economics, University of Niš. The major fields of his research interest are contemporary economic paradigms, evolutionary economics, economics of post-socialist transition, political economy of globalization, comparative capitalisms.

Dragan Petrovic is an Associate Professor at the Faculty of Economics of the University of Niš. He teaches the subjects of Foundations of Economics and the Political Economy (in the undergraduate studies), Methodology of Economic Sciences (in the Master's studies) and Methodology of Scientific Research (in the doctoral studies). He received his $\mathrm{PhD}$ in economics from the Faculty of Economics in Niš, in the scientific field of the general economic theory. The major fields of his research interest are economic theory and analysis, the economic methodology and the institutional economic theory. 